\title{
Effect of Novel Insecticide Molecules in Mulberry on Cocoon Parameters of Silkworm Bombyx mori L
}

\author{
M.P. Yeshika ${ }^{\text {* }}$, K.G. Banuprakash ${ }^{1}$, K. Murali Mohan ${ }^{2}$ and K.S. $\operatorname{Vinoda}^{3}$ \\ ${ }^{1}$ Department of Sericulture, UAS, GKVK, Bangalore - 560065, Karnataka, India \\ ${ }^{2}$ Department of Agricultural Entomology, UAS, GKVK, \\ Bangalore - 560065, Karnataka, India \\ ${ }^{3}$ Department of Silkworm Genetics and Breeding, College of Chintamani - 563125, India \\ *Corresponding author
}

Keywords

Mulberry silkworm, dinotefuron,

flonicamid, azadiractin, DDVP

Article Info

Accepted:

08 January 2020

Available Online:

10 February 2020

A B S T R A C T

Efficacy of novel insecticides on the cocoon parameters of mulberry silkworm Bombyx mori resulted in the maximum single cocoon weight of $1.81 \mathrm{~g}$ (10 DAS), $1.83 \mathrm{~g}$ (20 DAS), $1.90 \mathrm{~g}$ (30 DAS) and $1.87 \mathrm{~g}$ (40 DAS) in the untreated control. Pupal weight was recorded was recorded maximum in untreated control along with other insecticides viz., azadirachtin $1 \%$ @ 1 $\mathrm{ml}$, dinotefuran 20 SG@0.25\&0.12 g/l, pymetrozine 50 WG @0.6 g/l and buprofezin $25 \mathrm{SC} @ 1 \mathrm{ml} / 1$ at 10 and 20 Days After Spraying. Among the treatments untreated control exhibited maximum shell weight of 0.34 (20, 30 and 40 DAS) and $0.33 \mathrm{~g}$ at 10 DAS of insecticides which was on par with dichlorvos 76 EC @ 2.63 ml/1 (0.31g), dinotefuron 20SG @ 0.25 $\mathrm{g} / \mathrm{l}$ and pymetrozine $50 \mathrm{WG} @ 0.6 \mathrm{~g} / \mathrm{l}$. Hence proving, these green labelled insecticides as an effective alternate for dichlorovos in sericulture.

\section{Introduction}

India is the second largest silk producing country next only to China and sericulture is an integral part of the rural economy in an agrarian country like India. Mulberry is the sole food of silkworm Bombyx mori L. and is infested by several pests. These pests affect the growth of mulberry and cause considerable economic damage to the farmers. The insecticides applied for the management of mulberry pests have greater impact on silkworm. Pesticides leave residues on mulberry leaves which in turn affect the sensitive silkworm.

To overcome this problem, safe waiting period is very essential for leaf harvesting (Yokoyama, 1962). Sik et al., (1976) reported that more than 1.4 per cent of yield reduction in sericulture was due to side effect of pesticide application. 49.4 per cent was due to 
the application of different pesticides in rice fields, 21.2 per cent in fruit gardens and 12.3 per cent in olericulture. It was observed that there was loss of cocoon yield from silkworms which fed on mulberry leaves sprayed with insecticides (Narasimhanna, 1988).

Exposure to the residue of pesticides in the mulberry leaves could affect growth and quality of economic characteristics of cocoons. Pest management in mulberry sericulture is highly selective because silkworm cannot tolerate even sub lethal doses of toxic compounds.

Dichlorvos (DDVP) is the common insecticide used for management of sucking pests in mulberry. Newer chemicals with novel and specific mode of action have been introduced for management of sucking pests in other crops viz., cotton, grapes, chilli, sunflower etc.

However, the choices of newer insecticides require information against sucking insects in mulberry ecosystem, waiting period and residual toxicity.

Consequent to this, a study was initiated using different novel insecticides, corresponding waiting periods and residual toxicity to silkworm, especially on the cocoon parameters of silkworm $B$. mori L.

\section{Materials and Methods}

\section{Experimental layout}

The experiment was conducted at the Department of Sericulture, UAS, GKVK, Bengaluru with well-established mulberry garden of $\mathrm{V}_{1}$ variety fed to Kolar Gold which is a commercial cross breed $\left(\mathrm{PM} \times \mathrm{CSR}_{2}\right)$. The experiment was laid out in Completely Randomized Design with 13 treatments, each replicated three times.

\section{Treatment details}

Insecticides like buprofezin $25 \mathrm{SC} @(1 \mathrm{ml} / 1$ and $2 \mathrm{ml} / \mathrm{l})$, pymetrozine $50 \mathrm{WG} @(0.3 \mathrm{~g} / \mathrm{l}$ and $0.6 \mathrm{~g} / \mathrm{l})$, flonicamid $50 \mathrm{WG} @(0.15 \mathrm{~g} / \mathrm{l}$ and $0.3 \mathrm{~g} / \mathrm{l})$, dinotefuron 20 SG @ (0.12 g/l and $0.25 \mathrm{~g} / \mathrm{l})$, azadirachtin $1 \% @(1 \mathrm{ml} / \mathrm{l}$ and $2 \mathrm{ml} / \mathrm{l})$, dichlorvos 76 EC @ (1.32 ml/1 and $2.63 \mathrm{ml} / \mathrm{l}$ ) and untreated control were sprayed on the mulberry plants and care was taken by holding a polythene cover along the treated plants while spraying to ensure that there was no drifting of chemicals due to wind and the treated leaves were fed to the silkworms.

Before the commencement of silkworm rearing the appliances were sun dried and rearing room, appliances were thoroughly cleaned and the floor was washed using 2 per cent bleaching powder solution. Then the entire rearing room was later disinfected by following standard procedure (Dandin et al., 2003).

The rearing room was kept air tight for 24 hours and then the room was kept open and used for rearing. The third instar larvae were provided with chopped mulberry leaves of required quantity and quality.

After 30 minutes of initial feeding, 90 larvae were transferred to each experimental tray in thee replications along with the mulberry leaves.

Later, in order to assess extent of toxicity in insecticides to silkworm and to determine the safety period for effective molecules, the silkworm rearing was carried out.

Observations such as single cocoon weight (g), pupal weight $(\mathrm{g})$, cocoon shell weight $(\mathrm{g})$ and cocoon shell ratio (\%) were recorded during rearing. 
Table.1 Effect of insecticides on single cocoon weight (g)

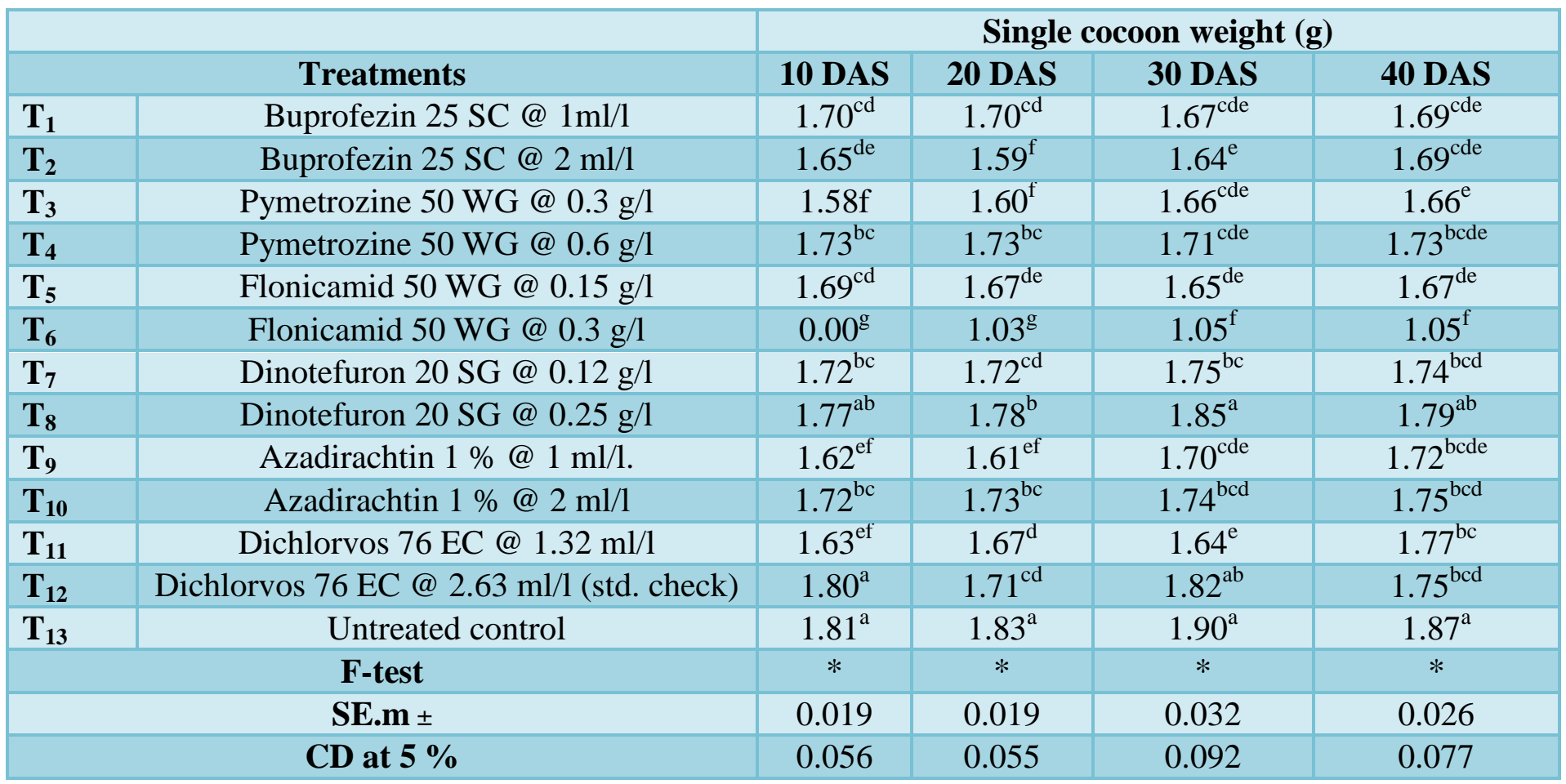

*Significant at $5 \%$, DAS - Days after spraying.

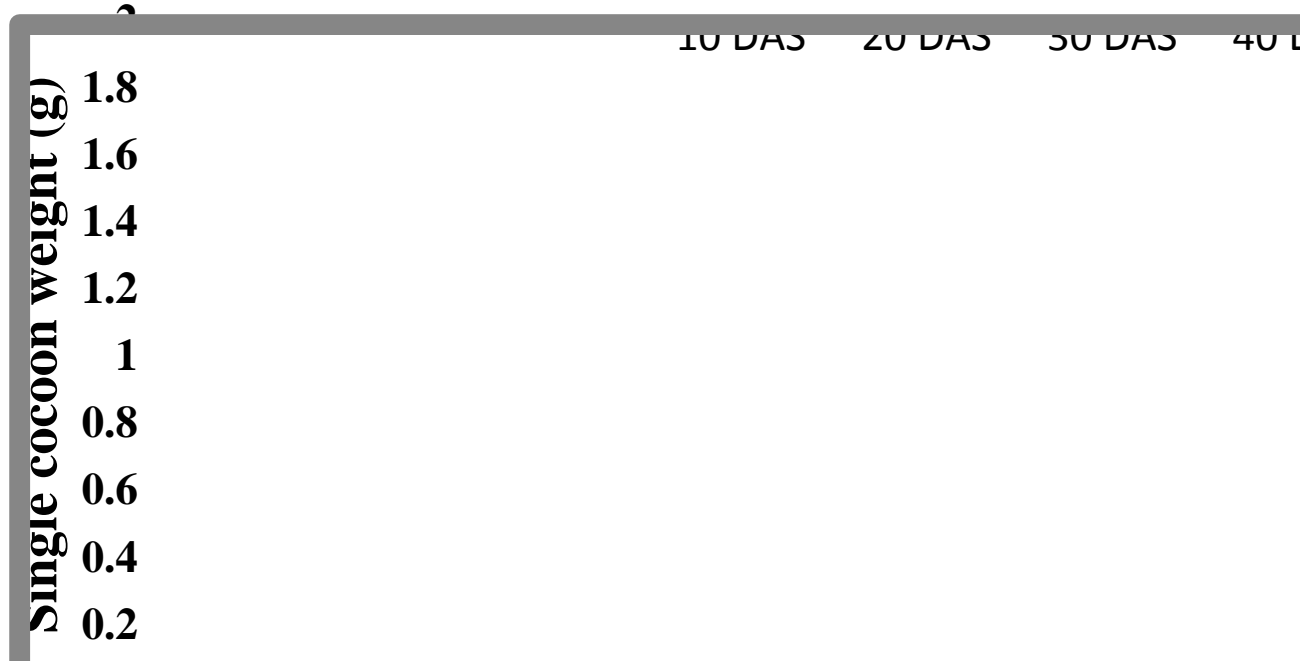

Fig.1 Effect of insecticides on Single cocoon weight (g)

$\mathbf{T}_{\mathbf{1}}$ - Buprofezin $25 \mathrm{SC} @ 1 \mathrm{ml} / 1$

$\mathbf{T}_{2^{-}}$Buprofezin $25 \mathrm{SC} @ 2 \mathrm{ml} / \mathrm{l}$

$\mathbf{T}_{3}$ - Pymetrozine 50 WG @ $0.3 \mathrm{~g} / 1$

$\mathbf{T}_{4}$ - Pymetrozine $50 \mathrm{WG} @ 0.6 \mathrm{~g} / 1$

$\mathbf{T}_{5}$ - Flonicamid 50 WG @ $0.15 \mathrm{~g} / \mathrm{l}$

$\mathbf{T}_{6}$ - Flonicamid 50 WG @ $0.3 \mathrm{~g} / 1$

$\mathbf{T}_{7^{-}}$Dinotefuron 20 SG @ $0.12 \mathrm{~g} / \mathrm{l}$
$\mathbf{T}_{\mathbf{8}^{-}}$Dinotefuron 20 SG @ $0.25 \mathrm{~g} / \mathrm{l}$

$\mathbf{T}_{\mathbf{9}}$ - Azadirachtin $1 \% @ 1 \mathrm{ml} / \mathrm{l}$

$\mathbf{T}_{10}$ - Azadirachtin 1\%@2 ml/1

$\mathbf{T}_{11}$ - Dichlorovas 76 EC @ $1.32 \mathrm{ml} / 1$

$\mathbf{T}_{12}$ - Dichlorovas 76 EC @ $2.63 \mathrm{ml} / 1$

$\mathbf{T}_{13}$ - Untreated control

DAS- Days after spraying 


\section{Results and Discussion}

\section{Single cocoon weight (g)}

The parameter Single cocoon weight (g) was found significant in all the four sets of DAS. The maximum cocoon weight was recorded in the treatment of untreated control $(1.81 \mathrm{~g})$ followed by dichlorvos 76 EC @ $2.63 \mathrm{ml} / \mathrm{l}$ $(1.80 \mathrm{~g})$ and dinotefuron $20 \mathrm{SG} @ 0.25 \mathrm{~g} / \mathrm{l}$ $(1.77 \mathrm{~g})$ which were significantly on par with each other.

The minimum cocoon weight was recorded in the treatment pymetrozine 50 WG @ $0.3 \mathrm{~g} / \mathrm{l}$ $(1.58 \mathrm{~g})$ which were significantly on par with azadiractin $1 \%$ @ $1 \mathrm{ml}(1.62 \mathrm{~g})$ and dichlorvos 76 EC @ $2.63 \mathrm{ml} / \mathrm{l}$ (1.63 g).

In the silkworm batches reared on 20 DAS minimum cocoon weight was recorded from the treatment flonicamid 50 WG @ $0.3 \mathrm{~g} / \mathrm{l}$ $(1.03 \mathrm{~g})$ and untreated control exhibited maximum cocoon weight of $1.83 \mathrm{~g}$. Buprofezin 25 SC @ $1 \mathrm{ml} / \mathrm{l}$, pymetrozine 50 WG @ 0.6 g/l, dinotefuron 20 SG @ 0.12 g/l, azadirachtin 1\%@2 ml/l and dichlorvos 76 EC @ $2.63 \mathrm{ml} / \mathrm{l}$ exhibited on par results like $1.70 \mathrm{~g}, 1.73 \mathrm{~g}, 1.72 \mathrm{~g}, 1.73 \mathrm{~g}$ and $1.71 \mathrm{~g}$ respectively. The treatments pymetrozine 50 WG@0.3 g/l, azadirachtin 1\% @ 1 ml/l and buprofezin 25 SC @ 2 ml/1 also recorded on par cocoon weight like $1.60 \mathrm{~g}, 1.61 \mathrm{~g}$ and 1.59 g respectively

Untreated control $(1.90 \mathrm{~g})$ yielded highest cocoon weight among the treatments in the silkworm batches of 30 DAS this was statistically on par with dinotefuron 20 SG @ $0.25 \mathrm{~g} / \mathrm{l}$ exhibiting cocoon weight of $1.85 \mathrm{~g}$ and dichlorvos 76 EC @ 2.63 ml/l which exhibited statistically on par values with it of $1.82 \mathrm{~g}$.

Cocoon weight of $1.75 \mathrm{~g}$ was recorded in dinotefuron 20 SG @ $0.12 \mathrm{~g} / \mathrm{l}$, followed by pymetrozine 50 WG @ 0.6 g/l (1.71 g), azadirachtin $1 \%$ @ $2 \mathrm{ml} / \mathrm{l}(1.74 \mathrm{~g})$, azadirachtin $1 \%$ @ $1 \mathrm{ml} / \mathrm{l}\left(\begin{array}{lll}1.70 & \mathrm{~g}\end{array}\right)$ the treatments like buprofezin 25 SC @ $1 \mathrm{ml} / \mathrm{l}$ (1.67 g), buprofezin $25 \mathrm{SC} @ 2 \mathrm{ml} / \mathrm{l}(1.64 \mathrm{~g})$, dichlorvos 76 EC @ $1.32 \mathrm{ml} / \mathrm{l}(1.64 \mathrm{~g})$, pymetrozine 50WG @ $0.3 \mathrm{~g} / \mathrm{l}(1.66 \mathrm{~g})$ and flonicamid 50 WG @ $0.15 \mathrm{~g} / \mathrm{l}\left(\begin{array}{lll}1.65 & \mathrm{~g}\end{array}\right)$ exhibited on par values. The minimum cocoon weight obtained was in the treatment flonicamid 50 WG @ $0.3 \mathrm{~g} / \mathrm{l}$ (1.05 g) (Table 1; Fig. 1).

On the 40 DAS of insecticides, the silkworm exhibited significant values for cocoon weight where the highest cocoon weight was recorded in the treatment untreated control $(1.87 \mathrm{~g})$ which was on par with and dinotefuron 20 SG @ 0.25 g/l (1.79 g) and the least cocoon weight was recorded in the treatment flonicamid 50 WG @ 0.3 g/l (1.05 g) (Table 1; Fig 1).

During the evaluation on efficacy of insecticides on the cocoon weight parameters the untreated control exhibited the highest cocoon weight of $1.81 \mathrm{~g}$ (10 DAS), $1.83 \mathrm{~g} \mathrm{(20}$ DAS), $1.90 \mathrm{~g}$ (30 DAS) and1.87 g (40 DAS).

Cocoon weight recorded in the treatment, dinotefuran 20 SG @ 0.25 g/l was on par with untreated control at 10,20,30 and 40 DAS. This was followed by azadirachtin 1\%@2 $\mathrm{ml} / \mathrm{l}$ at all the time intervals. Lowest cocoon weight was recorded in flonicamid 50WG @ $0.3 \mathrm{~g} / \mathrm{l}$ at $20 \mathrm{DAS}, 30 \mathrm{DAS}$ and 40 DAS.

Except dinotefuron, the decline in cocoon weight in general was noticed with all other insecticides assessed. Similarly, Bandyopadhyay et al., (2005) reported significant decline in the commercial characters like cocoon weight when silkworm larvae were fed with monocrotophos, acephate and dichlorvos and azadirachtin $1500 \mathrm{ppm} \& 300 \mathrm{ppm}$ which is in conformity with present results. 
Table.2 Effect of insecticides on single pupal weight (g)

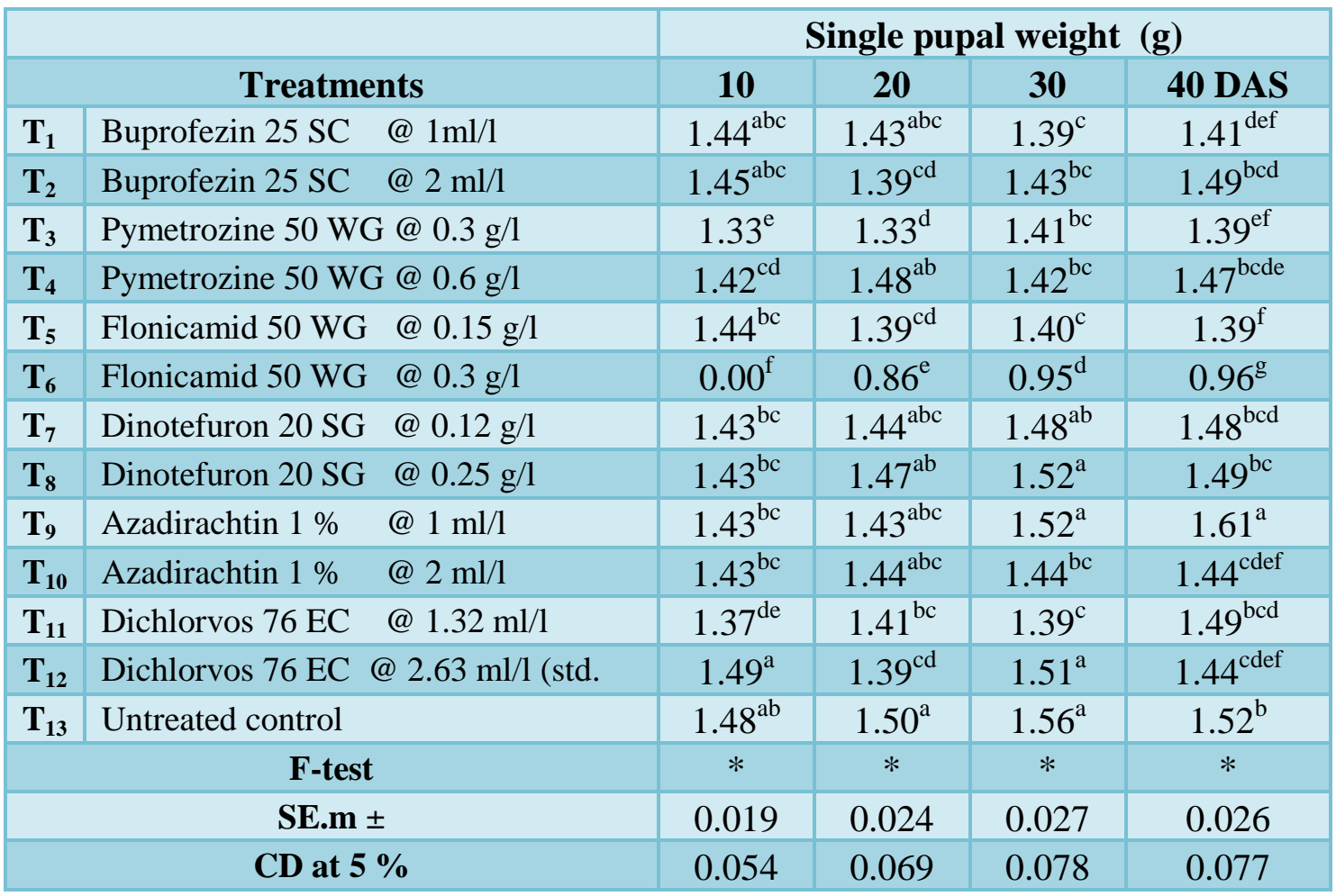

*Significant at $5 \%$, DAS - Days after spraying.

1.8

10DAS 2ODAS 3ODAS 4ODAS

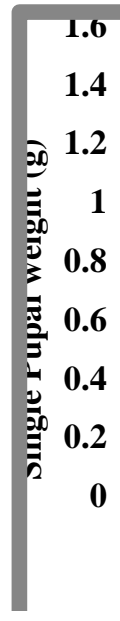

Treatments

Fig.2 Effect of insecticides on pupal weight (g)

$\mathbf{T}_{\mathbf{1}^{-}}$Buprofezin 25 SC @ 1ml/1

$\mathbf{T}_{2}$ - Buprofezin $25 \mathrm{SC} @ 2 \mathrm{ml} / \mathrm{l}$

$\mathbf{T}_{3}$ - Pymetrozine 50 WG @ $0.3 \mathrm{~g} / \mathrm{l}$

$\mathbf{T}_{4}$ - Pymetrozine $50 \mathrm{WG} @ 0.6 \mathrm{~g} / \mathrm{l}$

$\mathbf{T}_{5}$ - Flonicamid 50 WG @ $0.15 \mathrm{~g} / \mathrm{l}$

$\mathbf{T}_{6}$ - Flonicamid 50 WG @ $0.3 \mathrm{~g} / 1$

$\mathbf{T}_{7}$ - Dinotefuron 20 SG @ $0.12 \mathrm{~g} / \mathrm{l}$
$\mathbf{T}_{8^{-}}$Dinotefuron 20 SG @ $0.25 \mathrm{~g} / \mathrm{l}$

$\mathbf{T}_{\mathbf{9}^{-}}$Azadirachtin 1\% @ $1 \mathrm{ml} / \mathrm{l}$

$\mathbf{T}_{10^{-}}$Azadirachtin 1\% @ $2 \mathrm{ml} / \mathrm{l}$

$\mathbf{T}_{11}$ - Dichlorovas 76 EC @ $1.32 \mathrm{ml} / \mathrm{l}$

$\mathbf{T}_{12}$ - Dichlorovas 76 EC @ $2.63 \mathrm{ml} / \mathrm{l}$

$\mathbf{T}_{13^{-}}$Untreated control

DAS- Days after spraying 


\section{Single pupal weight $(g)$}

Among the silkworm batches reared on 10 DAS, the pupal weight of each treatment differed significantly from each other, as the treatment dichlorvos 76 EC @ 2.63 ml/l exhibited maximum weight $(1.49 \mathrm{~g})$ which was statistically on par with untreated control (1.48 g), buprofezin $25 \mathrm{SC} @ 2 \mathrm{ml} / \mathrm{l}(1.45 \mathrm{~g})$, buprofezin 25 SC @ 1 ml/l $(1.44 \mathrm{~g})$, flonicamid 50 WG @ $0.15 \mathrm{~g} / \mathrm{l}(1.44 \mathrm{~g})$. Dichlorvos 76 EC @ $1.32 \mathrm{ml} / \mathrm{l}$ yeilded $1.37 \mathrm{~g}$ pupal weight followed by pymetrozine 50 WG@ $0.3 \mathrm{~g} / 1$ which exhibited the lowest pupal weight (1.33 g) (Table 2; Fig. 2).

On 20 DAS the silkworm batches reared expressed significant difference in the values for pupal weight, where the maximum pupal weight was recorded in the untreated control $(1.50 \mathrm{~g})$ and flonicamid $50 \mathrm{WG} @ 0.3 \mathrm{~g} / \mathrm{l}$ recorded the lowest pupal weight $(0.86 \mathrm{~g})$.

Dichlorvos 76 EC @ $1.32 \mathrm{ml} / 1$ recorded pupal weight of $1.41 \mathrm{~g}$ which exhibited on par values with the treatments buprofezin $25 \mathrm{SC}$ @ $2 \mathrm{ml} / \mathrm{l}$ (1.39 g), flonicamid 50 WG @ 0.15 $\mathrm{g} / \mathrm{l}(1.39 \mathrm{~g})$ and dichlorvos $76 \mathrm{EC} @ 2.63 \mathrm{ml} / \mathrm{l}$ (1.39 g). Pymetrozine 50 WG @ $0.3 \mathrm{~g} / \mathrm{l}$ recorded lowest pupal weight of $1.33 \mathrm{~g}$.

There was significant difference among the treatments in the silkworm batches reared on 30 DAS. Untreated control (1.56 g) recorded the maximum weight of pupa which was statistically on par with the treatments dinotefuron 20 $\quad$ SG @ $0.25 \mathrm{~g} / 1 \quad(1.52 \mathrm{~g})$, azadirachtin $1 \%$ @ $\left.\quad \begin{array}{lllll} & \mathrm{ml} / \mathrm{l} & (1.52 & \mathrm{g}\end{array}\right)$, dichlorvos 76 EC @ $2.63 \mathrm{ml} / \mathrm{l}(1.51 \mathrm{~g})$ and dinotefuron 20 SG @ $0.12 \mathrm{~g} / \mathrm{l}(1.48 \mathrm{~g})$. The minimum pupal weight was recorded in flonicamid 50 WG @ $0.3 \mathrm{~g} / \mathrm{l}$ (0.95 g) (Table 2; Fig. 2).

Pupal weight recorded was highest in untreated control along with other insecticides viz., azadirachtin1\%@1 ml, dinotefuran 20 SG @ $0.25 \& 0.12 \mathrm{~g} / \mathrm{l}$, pymetrozine $50 \mathrm{WG}$ @ $0.6 \mathrm{~g} / \mathrm{l}$ and buprofezin $25 \mathrm{SC} @ 1 \mathrm{ml} / \mathrm{l}$ at 10 DAS and 20 DAS. At 40 DAS, highest pupal weight was recorded in azadirachtin 1\% @ $1 \mathrm{ml} / \mathrm{l}(1.61 \mathrm{~g})$ which was on par with untreated control $(1.52 \mathrm{~g})$.

The lowest pupal weight was observed in flonicamid 50WG @ $0.3 \mathrm{~g} / \mathrm{l}$ at 20,30 and 40 days after spraying. Similar to these findings, Maria et al., (2000) studied the effects of buprofezin on the growth of silkworm and concluded that among the different insecticides treated buprofezin gave higher pupal weight of $1.5 \mathrm{~g} /$ cocoon.

However, studies by Gayathri (2007) exhibited that application of methy demeton, dimethoate, DDVP and azadirchtin did not differ significantly among them in respect of pupal weight.

Contrarily, when the larvae were fed with $4^{\text {th }}$ instar onwards, there was a significant increase in pupal weight with increase in days after the spray.

\section{Single cocoon Shell weight (g)}

The result obtained from the treated batches of worms from 10 DAS exhibited significant difference among the treatments where the maximum cocoon shell weight was observed in the treatment dinotefuron $20 \mathrm{SG} @ 0.25 \mathrm{~g} / \mathrm{l}$ $(0.34 \mathrm{~g})$, it was followed by untreated control $(0.33 \mathrm{~g})$, pymetrozine $50 \mathrm{WG} @ 0.6 \mathrm{~g} / \mathrm{l}$ and dichlorvos 76 EC @ 2.63 ml/l (standard Check) which exhibited similar results of shell weight $(0.31 \mathrm{~g})$ and were also on par with each other.

The least shell weight was obtained from the treatment azadirachtin 1\%@1 ml/l (0.19 g) which was statistically on par with buprofezin $25 \mathrm{SC} @ 1 \mathrm{ml} / \mathrm{l}(0.21 \mathrm{~g})$. 
Table.3 Effect of insecticides on single cocoon shell weight (g)

\begin{tabular}{|c|c|c|c|c|c|}
\hline \multirow{2}{*}{\multicolumn{2}{|c|}{ Treatments }} & \multicolumn{4}{|c|}{ Single cocoon shell weight (g) } \\
\hline & & \multirow{2}{*}{$\begin{array}{c}10 \text { DAS } \\
0.25^{\mathrm{e}}\end{array}$} & \multirow{2}{*}{$\begin{array}{c}20 \\
0.27^{\mathrm{d}}\end{array}$} & \multirow{2}{*}{$\begin{array}{c}30 \\
0.28^{\mathrm{de}}\end{array}$} & \multirow{2}{*}{$\begin{array}{c}40 \\
0.28^{\mathrm{cd}}\end{array}$} \\
\hline $\mathbf{T}_{1}$ & Buprofezin 25 SC @1ml/1 & & & & \\
\hline $\mathbf{T}_{2}$ & Buprofezin 25 SC @ 2 ml/1 & $0.21^{\mathrm{f}}$ & $0.21^{\mathrm{e}}$ & $0.20^{\mathrm{g}}$ & $0.20^{\mathrm{e}}$ \\
\hline $\mathbf{T}_{3}$ & Pymetrozine 50 WG @0.3 g/l & $0.25^{\mathrm{e}}$ & $0.27^{\mathrm{cd}}$ & $0.25^{\mathrm{f}}$ & $0.27^{\mathrm{cd}}$ \\
\hline $\mathbf{T}_{4}$ & Pymetrozine 50 WG @0.6g/1 & $0.31 b^{c}$ & $0.26^{\mathrm{d}}$ & $0.29^{\mathrm{cd}}$ & $0.26^{\mathrm{d}}$ \\
\hline $\mathbf{T}_{5}$ & Flonicamid 50 WG @0.15 g/l & $0.26^{\mathrm{e}}$ & $0.28^{\mathrm{cd}}$ & $0.24^{\mathrm{f}}$ & $0.29^{b c}$ \\
\hline $\mathbf{T}_{6}$ & Flonicamid 50 WG @0.3g/1 & $0.00^{\mathrm{g}}$ & $0.17^{\mathrm{e}}$ & $0.10^{\mathrm{h}}$ & $0.09^{\mathrm{f}}$ \\
\hline $\mathbf{T}_{7}$ & Dinotefuron 20 SG @0.12 g/1 & $0.28^{\mathrm{d}}$ & $0.28^{\mathrm{cd}}$ & $0.26^{\mathrm{ef}}$ & $0.26^{\mathrm{d}}$ \\
\hline $\mathbf{T}_{8}$ & Dinotefuron20 SG @0.25 g/l & $0.34^{\mathrm{a}}$ & $0.31^{\mathrm{abc}}$ & $0.32^{\mathrm{ab}}$ & $0.30^{\mathrm{b}}$ \\
\hline $\mathbf{T}_{9}$ & Azadirachtin1\%@1 ml/1 & $0.19 \mathrm{f}$ & $0.18^{\mathrm{e}}$ & $0.18^{\mathrm{g}}$ & $0.11^{\mathrm{f}}$ \\
\hline $\mathbf{T}_{10}$ & Azadirachtin 1\%@2 ml/1 & $0.29^{\mathrm{cd}}$ & $0.29^{\mathrm{bcd}}$ & $0.30^{\text {bed }}$ & $0.31^{\mathrm{b}}$ \\
\hline $\mathbf{T}_{11}$ & Dichlorvos76 EC @ 1.32 ml/1 & $0.26^{\mathrm{e}}$ & $0.26^{\mathrm{d}}$ & $0.25^{\mathrm{f}}$ & $0.28^{\mathrm{cd}}$ \\
\hline $\mathbf{T}_{12}$ & Dichlorvos 76 EC @ 2.63 ml/l (std. check) & $0.31^{\mathrm{bc}}$ & $0.33^{\mathrm{ab}}$ & $0.31^{\mathrm{bc}}$ & $0.31^{\mathrm{b}}$ \\
\hline $\mathbf{T}_{13}$ & Untreated control & $0.33^{\mathrm{ab}}$ & $0.34^{\mathrm{a}}$ & $0.34^{\mathrm{a}}$ & $0.34^{\mathrm{a}}$ \\
\hline & F-test & $*$ & $*$ & $*$ & $*$ \\
\hline & SE.m \pm & 0.009 & 0.015 & 0.010 & 0.007 \\
\hline & CD at $5 \%$ & 0.026 & 0.042 & 0.028 & 0.021 \\
\hline
\end{tabular}

*Significant at $5 \%$, DAS - Days after spraying.

10 DAS 20 DAS 30 DAS 40 DAS

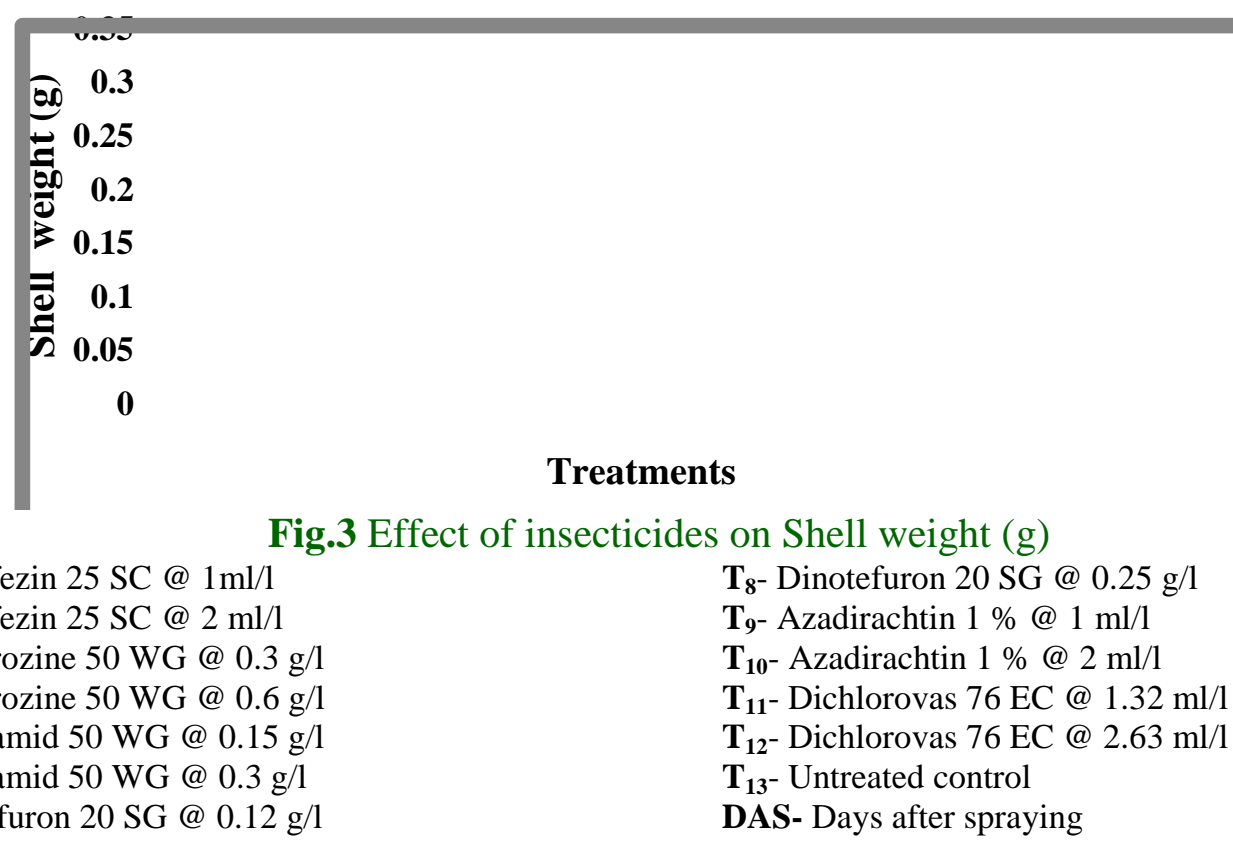


The silkworms reared by feeding mulberry leaves 20 DAS of insecticides have recorded significant difference among treatments, where the untreated control yielded maximum single cocoon shell weight $(0.34 \mathrm{~g})$, which was statistically on par with insecticide treated batches viz., dichlorvos 76 EC @ 2.63 $\mathrm{ml} / \mathrm{l}$ (Standard Check) (0.33 g), dinotefuron 20 SG@0.25 g/l (0.31 g) and azadirachtin 1 $\%$ @ $2 \mathrm{ml} / 1$ (0.29 g). The minimum cocoon shell weight was recorded in the treatment flonicamid 50 WG @ 0.3 g/l (0.17 g) which was on par with azadirachtin $1 \%$ @ $1 \mathrm{ml} / \mathrm{l}$ (0.18 g). Whereas buprofezin 25 SC @ $1 \mathrm{ml} / \mathrm{l}$, pymetrozine $50 \mathrm{WG} @ 0.3 \mathrm{~g} / \mathrm{l}$, pymetrozine 50 WG@0.6 g/l, flonicamid50 WG@0.15 $\mathrm{g} / \mathrm{l}$, dinotefuron 20 SG @ $0.12 \mathrm{~g} / \mathrm{l}$ and dichlorvos 76 EC @ $1.32 \mathrm{ml} / 1$ were found on par with each other. Significant values were recorded in the batches of silkworms fed with mulberry leaves 30 DAS of insecticides. Here also untreated control $(0.34 \mathrm{~g})$ has yielded maximum cocoon shell weight which was on par with dinotefuron $20 \mathrm{SG}$ @ $0.25 \mathrm{~g} / \mathrm{l}(0.32$ g), dichlorvos 76 EC @ 2.63 ml/l (standard Check) (0.31 g) and azadirachtin 1\%@2 $\mathrm{ml} / \mathrm{l}(0.30 \mathrm{~g})$. Flonicamid 50 WG @ $0.3 \mathrm{~g} / \mathrm{l}$ has yielded very less cocoon shell weight $(0.10 \mathrm{~g})$. The rest of the treatments possess the single cocoon shell weight varying from $0.18 \mathrm{~g}$ to $0.3 \mathrm{~g}$ (Table 3; Fig. 3).

The significant higher single cocoon shell weight was recorded in untreated control $(0.34 \mathrm{~g})$ in the batches reared on 40 DAS which was on par with treatments of insecticides azadirachtin 1\%@2 ml/l and dichlorvos 76 EC @ 2.63 ml/l (standard Check) which exhibited the similar values (0.31 g).

Flonicamid 50 WG @0.3 g/l has yielded very less cocoon shell weight $(0.09 \mathrm{~g})$. The rest of the treatments possess the single cocoon shell weight varying from $0.20 \mathrm{~g}$ to $0.3 \mathrm{~g}$. Among the treatments untreated control exhibited highest shell weight of 0.34 (20, 30 and 40 DAS) and $0.33 \mathrm{~g}$ at 10 DAS of insecticides. This was on par with dichlorvos 76 EC @ $2.63 \mathrm{ml} / 1$ (0.31g), dinotefuron 20SG @0.25 $\mathrm{g} / \mathrm{l}$ and pymetrozine $50 \mathrm{WG} @ 0.6 \mathrm{~g} / \mathrm{l}$.

At 20, 30 and 40 DAS, shell weight was highest in untreated control and the values were on par with the shell weight recorded in dichlorvos $76 \quad$ EC @ $2.63 \quad \mathrm{ml} / 1$ and dinotefuron 20SG @ 0.25 g/l.

Azadirachtin $1 \% \quad(1 \mathrm{ml} / 1)$ recoded significantly lower shell weight at 10, 20, 30 and 40 DAS as compared to untreated control. Similarly, Narayanaswamy et al., (2017) reported significantly lower shell weight when worms were fed with NSKE $4 \%$ treated leaves harvested after 16th, 17th, $18 \mathrm{th}, 19^{\text {th }}$ day after spray.

In another study, similar to the current findings, buprofezin 25SC @ 1 ml/l exhibited decline in the shell weight when larvae of silkworm Bombyx mori were fed with treated leaves harvested at 20, 30 and 40 DAS (Maria et al., 2000).

\section{Cocoon Shell ratio $(\%)$}

Dinotefuron 20 SG @ 0.25 g/l (19.24 \%) has recorded maximum cocoon shell ratio, was found statistically on par with untreated control (18.38\%) and pymetrozine 50 WG @ $0.6 \mathrm{~g} / \mathrm{l}(17.92 \%)$. The lowest cocoon shell ratio was found in azadirachtin $1 \%$ @ $1 \mathrm{ml} / \mathrm{l}$ $(11.55 \%)$ which was on par with buprofezin 25 SC @ 2 ml/l (12.50\%). The other treatments possess cocoon shell ratio from 14.94 to 17.18 per cent (Table 4; Fig. 4).

Dichlorvos 76 EC @ 2.63 ml/l (standard Check) resulted in maximum cocoon shell ratio $(19.08 \%)$. This was statistically on par with untreated control (18.37\%), dinotefuron 20.SG@0.25 g/1 (17.44\%), flonicamid 50 
WG@0.15 g/l (16.97\%), azadirachtin 1\%@ $2 \mathrm{ml} / 1$ (16.92\%), pymetrozine 50 WG @0.3 g/1 (16.85\%) and flonicamid 50 WG @0.3 g/l (16.62\%). The lowest cocoon shell ratio was exhibited by azadirachtin $1 \%$ @ $1 \mathrm{ml} / \mathrm{l}$ $(11.15 \%)$ which is on par with buprofezin 25 SC @ 2 ml/1 (12.97\%).

When the silkworms were fed with mulberry leaves 30 DAS of insecticides, the maximum cocoon shell ratio was recorded in dinotefuron 20 SG @ $0.25 \mathrm{~g} / 1$ (17.49 \%), which is on par with the highest cocoon shell ratio possessed by untreated control (17.92 \%). Whereas dinotefuron 20 SG @ $0.25 \mathrm{~g} / \mathrm{l}$ was on par with azadirachtin 1\%@2 ml/1 (17.27\%), pymetrozine 50 WG @ $0.6 \mathrm{~g} / \mathrm{l}$ (17.17\%), dichlorvos 76 EC @ 2.63 ml/l (standard Check) (16.99\%) and buprofezin 25 SC @ 1 ml/l (16.80\%). The lowest value among the treatments was recorded in flonicamid 50 WG @0.3 g/l (9.54\%) which was statistically on par with azadirachtin $1 \%$ @ $1 \mathrm{ml} / \mathrm{l}(10.41 \%)$.

The cocoon shell ratio varied from 6.20 to 17.83 per cent, when the silkworms were reared with the mulberry leaves fed with 40 DAS of insecticides. The untreated control has yielded highest cocoon shell ratio (18.40 $\%)$. Among the treated batches dichlorvos 76 EC @ $1.32 \mathrm{ml} / \mathrm{l}(17.83 \%)$ has resulted in maximum cocoon shell ratio, which was found on par with dichlorvos 76 EC @ 2.63 $\mathrm{ml} / \mathrm{l}$ (standard Check) (17.59\%), azadirachtin $1 \% @ 2 \mathrm{ml} / 1$ (17.53\%) and flonicamid 50 WG @ $0.15 \mathrm{~g} / \mathrm{l}(17.13 \%)$. The lowest value among the treatments was recorded in azadirachtin $1 \% @ 1$ ml/l (06.20\%) (Table 4; Fig. 4).

The silkworm batch reared by feeding mulberry leaves 10 days after spraying of insecticides recorded highest cocoon shell ratio in the treatment dinotefuron 20SG @ $0.25 \mathrm{~g} / \mathrm{l}(19.24 \%)$ and the lowest shell ratio was recorded in the treatment azadirachtin $1 \%$ @ $2 \mathrm{ml} / \mathrm{l}(11.55 \%)$.

Similar finding were reported by Manoja et al., (2011) wherein, thiamethexam $(0.015 \%)$ treated mulberry leaves fed to silkworms exhibited an increased shell ratio of $17.35 \%$ over control.

Dinotefuran belongs to the same group of insecticides (neonicotinods) as that of thiamethaxam and the current findings are in conformity with this report. On 20 days after spraying, highest cocoon shell ratio was recorded in the treatment dichlorvos 76 EC @ $2.63 \mathrm{ml} / \mathrm{l}(19.08 \%)$.

Lowest cocoon shell ratio was observed in azadirachtin 1\%@1 ml/1 at $20(11.15 \%)$. At 30 days after spraying, highest cocoon shell ratio of $17.92 \%$ was recorded in the untreated control and the lowest shell ratio was recorded in the treatment flonicamid $50 \mathrm{WG}$ @ $0.3 \mathrm{~g} / 1(9.54 \%)$.

When silkworms were fed with leaves harvested at 40 days after spraying, the highest cocoon shell ratio was recorded in untreated control $(18.40 \%)$ and the lowest cocoon shell weight was recorded in azadirachtin 1\%@1 ml/1 (6.20\%).

Contrary to the current findings, Bandyopadhyay et al., (2013) observed $19 \%$ shell ratio when silkworms were fed with $1 \%$ neem oil treated mulberry leaves. Shell ratio recorded here was on par with the ratio observed in untreated control.

Gayathri (2007) reported the adverse effects insecticides on shell ratio. Here, when fourth instar silkworms were fed with organophosphate insecticide, methyl demeton $(0.05 \%)$, cocoon shell ratio was significantly lower than that of untreated control. 
Table.4 Effect of insecticides on cocoon shell ratio (\%)

\begin{tabular}{|c|c|c|c|c|c|}
\hline \multicolumn{2}{|r|}{ Treatments } & \multicolumn{4}{|c|}{ Cocoon shell ratio (\%) } \\
\hline & & 10 DAS & 20 DAS & 30 DAS & 40 DAS \\
\hline $\mathbf{T}_{1}$ & Buprofezin 25 SC @ 1ml/1 & $14.94^{\mathrm{f}}$ & $15.73^{b c}$ & $16.80^{\mathrm{a}}$ & $16.56^{\mathrm{bc}}$ \\
\hline $\mathbf{T}_{2}$ & Buprofezin 25 SC @ 2 ml/l & $12.50^{\mathrm{g}}$ & $12.97^{\mathrm{de}}$ & $12.43^{\mathrm{c}}$ & $12.05^{\mathrm{e}}$ \\
\hline $\mathbf{T}_{\mathbf{3}}$ & Pymetrozine 50 WG @ $0.3 \mathrm{~g} / \mathrm{l}$ & $15.81^{\mathrm{def}}$ & $16.85^{\mathrm{abc}}$ & $15.02^{\mathrm{b}}$ & $16.08^{\mathrm{cd}}$ \\
\hline $\mathbf{T}_{4}$ & Pymetrozine 50 WG @ 0.6 g/l & $17.92^{\mathrm{abc}}$ & $14.85^{\mathrm{cd}}$ & $17.17^{\mathrm{a}}$ & $15.07^{\mathrm{d}}$ \\
\hline$T_{5}$ & Flonicamid 50 WG @ 0.15 g/l & $15.17^{\text {ef }}$ & $16.97^{\mathrm{abc}}$ & $14.79^{\mathrm{b}}$ & $17.13^{\mathrm{abcf}}$ \\
\hline$T_{6}$ & Flonicamid 50WG @ 0.3 g/l & $0.00^{\mathrm{h}}$ & $16.62^{\mathrm{abc}}$ & $9.54^{\mathrm{d}}$ & $8.57^{\mathrm{d}}$ \\
\hline $\mathbf{T}_{7}$ & Dinotefuron 20 SG @ $0.12 \mathrm{~g} / \mathrm{l}$ & $16.51^{\text {cde }}$ & $16.31^{\mathrm{bc}}$ & $15.09^{\mathrm{b}}$ & $14.91^{\mathrm{bc}}$ \\
\hline $\mathbf{T}_{8}$ & Dinotefuron 20 SG @ 0.25 g/l & $19.24^{\mathrm{a}}$ & $17.44^{\mathrm{abc}}$ & $17.49^{\mathrm{a}}$ & $16.90^{\mathrm{g}}$ \\
\hline $\mathbf{T}_{9}$ & Azadirachtin 1\%@1 ml/1 & $11.55^{\mathrm{g}}$ & $11.15^{\mathrm{e}}$ & $10.41^{\mathrm{d}}$ & $6.20^{\mathrm{ab}}$ \\
\hline $\mathbf{T}_{10}$ & Azadirachtin 1\%@2 ml/l & $16^{88 \mathrm{~cd}}$ & $16.92^{\mathrm{abc}}$ & $17.27^{\mathrm{a}}$ & $17.53^{\mathrm{cd}}$ \\
\hline $\mathbf{T}_{11}$ & Dichlorvos76 EC @ 1.32 ml/l & $15.73^{\mathrm{def}}$ & $15.54^{\mathrm{cd}}$ & $15.01^{\mathrm{b}}$ & $17.83^{\mathrm{cd}}$ \\
\hline $\mathbf{T}_{12}$ & $\begin{array}{c}\text { Dichlorvos } 76 \text { EC @ } 2.63 \text { ml/1 (std. } \\
\text { check) }\end{array}$ & $17.18^{\mathrm{bcd}}$ & $19.08^{\mathrm{a}}$ & $16.99^{\mathrm{a}}$ & $17.59^{\mathrm{ab}}$ \\
\hline $\mathbf{T}_{13}$ & Untreated control & $18.38^{\mathrm{ab}}$ & $18.37^{\mathrm{ab}}$ & $17.92^{\mathrm{a}}$ & $18.40^{\mathrm{a}}$ \\
\hline & F-test & * & $*$ & $*$ & * \\
\hline & SE.m \pm & 0.507 & 0.935 & 0.457 & 0.464 \\
\hline & CD at $5 \%$ & 1.474 & 2.718 & 1.330 & 1.349 \\
\hline
\end{tabular}

*Significant at $5 \%$, DAS - Days after spraying. 


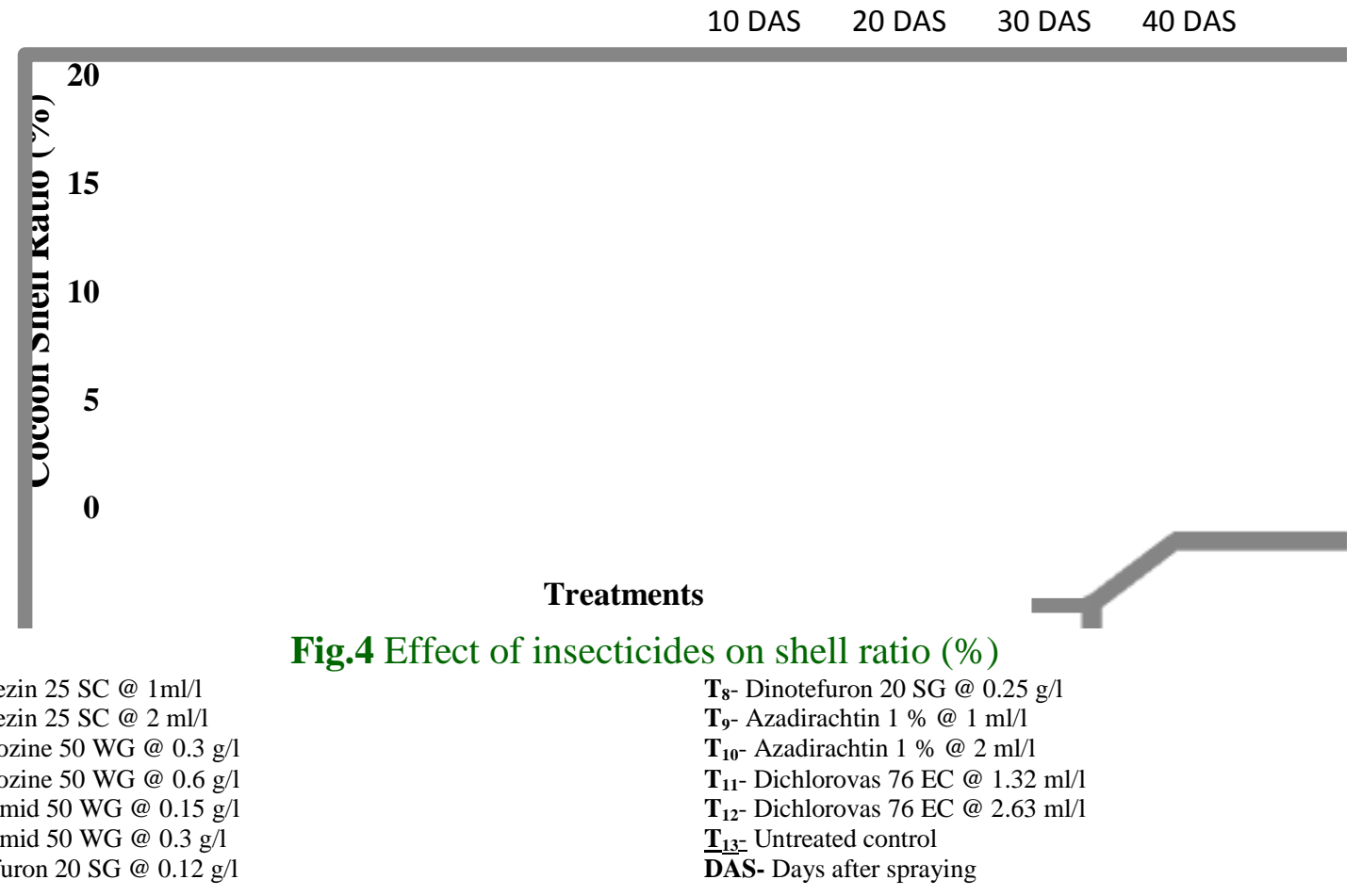

Plate.11 Cocoon formation among the silkworm batches treated with insecticides

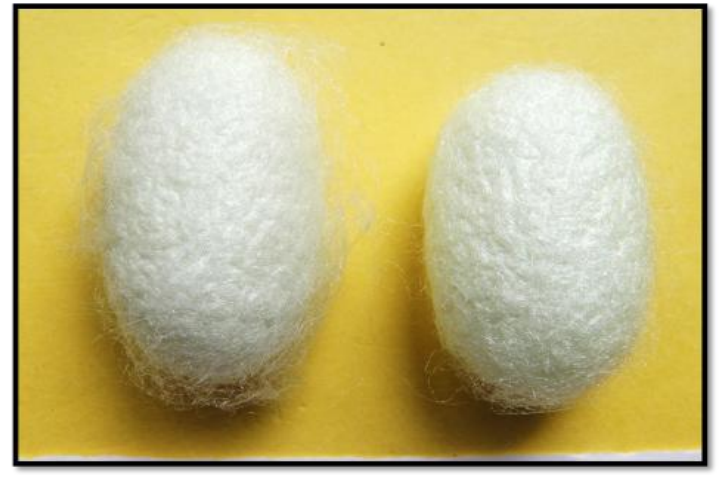

Cocoons got in the treatment dinotefuron 25 SG@0.25 g/l

The evaluation on efficacy of insecticides on the cocoon weight parameters the untreated control exhibited the highest cocoon weight in every batch reared by feeding the silkworms with mulberry at $10,20,30$ and 40 DAS. Dinotefuran $\quad 20 \quad$ SG $@ 0.25 \quad \mathrm{~g} / \mathrm{l}$ and azadirachtin 1\%@2 ml/l also exhibited higher cocoon weight along with control and the lowest cocoon weight was recorded in flonicamid 50WG@0.3 g/l at 20 DAS, 30

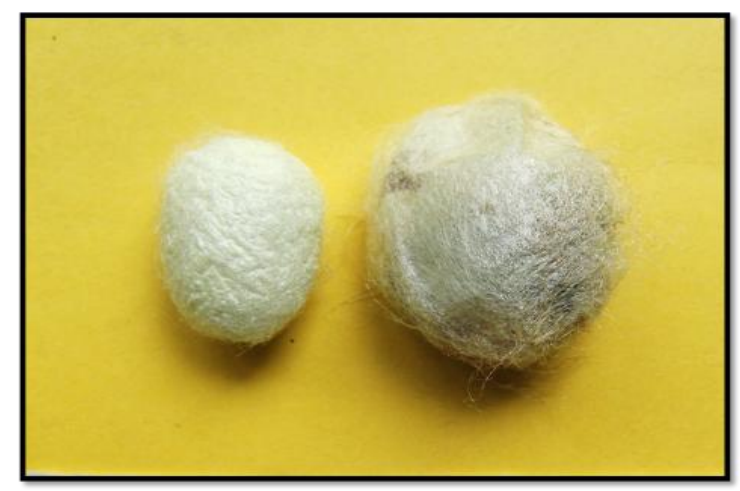

Cocoons got in the treatment flonicamid 50 WG@ $0.3 \mathrm{~g} / \mathrm{l}$

DAS and 40 DAS this may be due to the residual action of flonicamid in mulberry and even though flonicamid is a selective feeding blocker specific to sucking insects with repellent action, it appears that silkworms have lower tolerance limits for this molecule and the weight of the cocoon is altered. Pupal weight recorded was highest in untreated control along with other insecticides viz., azadirachtin1\%@1 ml, dinotefuran 20 SG 
@ $0.25 \& 0.12 \mathrm{~g} / \mathrm{l}$, pymetrozine $50 \mathrm{WG}$ @ $0.6 \mathrm{~g} / 1$ and buprofezin $25 \mathrm{SC} @ 1 \mathrm{ml} / \mathrm{l}$ at 10 DAS and 20 DAS. At 40 DAS, highest pupal weight was recorded in azadirachtin $1 \%$ @ $1 \mathrm{ml} / 1$ (1.61 g) which was on par with untreated control (1.52 g).

The lowest pupal weight was observed in flonicamid 50WG @ 0.3 g/l at 20,30 and 40 days after spraying. The untreated control exhibited highest shell weight of 0.34 (20, 30 and 40 DAS) and $0.33 \mathrm{~g}$ at 10 DAS of insecticides which was on par with the shell weight recorded in dichlorvos 76 EC @ 2.63 $\mathrm{ml} / \mathrm{l}$ and dinotefuron 20SG @ $0.25 \mathrm{~g} / \mathrm{l}$ whereas azadirachtin $1 \%(1 \mathrm{ml} / \mathrm{l})$ recoded lower shell weight at 10, 20, 30 and 40 DAS as compared to untreated control.

The silkworm batch reared by feeding mulberry leaves 10 days after spraying of insecticides recorded highest cocoon shell ratio in the treatment dinotefuron 20SG @ $0.25 \mathrm{~g} / \mathrm{l}(19.24 \%)$ and the lowest shell ratio was recorded in the treatment azadirachtin 1\% @ $2 \mathrm{ml} / \mathrm{l}$ (11.55 \%). On 20 days after spraying, highest cocoon shell ratio was recorded in the treatment dichlorvos76 EC @ $2.63 \mathrm{ml} / 1(19.08 \%)$.

Lowest shell ratio was observed in azadirachtin 1\%@1 ml/l at 20 (shell ratio of $11.15 \%$ ). At 30 days after spraying, highest cocoon shell ratio of $17.92 \%$ was recorded in the untreated control and the lowest shell ratio was recorded in the treatment flonicamid 50 WG@0.3 g / 1 (9.54\%). When silkworms were fed with leaves harvested at 40 days after spraying, the highest cocoon shell ratio was recorded in untreated control $(18.40 \%)$ and the lowest cocoon shell weight was recorded in azadirachtin 1\% @ 1 ml/l (6.20 $\%)$. By considering these facts dinotefuron 20SG along with azadiractin and pymetrozine can be used as an effective substitute for DDVP in Sericulture.

\section{References}

Bandyopadhyay, U. K. Chatterjee, S. maji, C. and Bindroo, B. B. 2013. Efficacy of plant oils against leaf webber (Glyphodes pyloalis Walker) on mulberry (Morus alba L.). Annals of Plant Protection Sciences 44(8): 49-53.

Bandyopadhyay, U.K. Santhakumar, M.V. and Saratchandra, B. 2005. Role of insecticides and botanicals in regulating whitefly (Dialeuropora decempuncta) incidence and their influence on some economic traits of silkworm (Bombyx mori L.). Annals of Plant Protection Sciences 13 (1): 48-53.

Dandin, S.B. Jayaswal, J. and Giridhar, K. 2003. Handbook of Sericulture Technologies. CSB, Bangalore. P.287.

Gayathri, M., 2007. Studies on tukra and powdery mildew diseases in mulberry and their impact on the growth and development of silkworm, B. Mori. M.Sc. (Agri.) Thesis, ANGRAU Bapatla P.42-112.

Kumutha, P. Padmalatha, C. and Ranjit Singh, A. J. A. 2013. Effect of pesticides on the reproductive performance and longevity of Bombyx mori L. International Journal of Current Microbiology and Applied Sciences 2(9):74-78.

Kumutha , P. Padmalatha, C, Sam Manohar Doss, S. and Aranjit Singh, A. J. A. 2009. Toxicity evaluation of neem oil and metacid on the development of the silkworm, Bombyx mori L. Uttar Pradesh Journal of Zoology 29(4) :220222.

Li, H.Y. Huang,W. J, Xie, J. L, Qin Bao, B. Q. and We, R. $1995 . \quad$ Three organophosphate insecticides on mulberry thrips control and their residual toxicities on silkworm. Acta Sericologica Sinica. 03(1):698-700.

Ma hui, Wang kaiyun, Wang hongyan. and 
Sishuding. 2006. Selective toxicity of chlorfenapyr between mulberry silkworms and mulberry pests. Acta Entomologica Sinica. 49(4):599-603.

Manoja, P. Bhattacharya, D. K. Kar, B. Das, N. K. Saha, A. K. and Bindroo, B. B. 2011. Potential efficacy of new pesticides for the control of mulberry whitefly and its impact on silkworm rearing. Journal of Plant Protection and Science 3(1) : 57-60.

Maria, E. V. Paschalis, C.H. and Sergios, K. 2000. Effects of applaud on the growth of silkworm (Lepidoptera: Bombycidae). Journal of Economic Entomology 93(2):290-292.
Narasimhanna, M. N. 1988. Manual on silkworm egg production. CSB, Bangalore, pp: 146.

Narayanaswamy, K. C. Harish, B.S. and Jagadish, K. S. 2017. Effect of NSKE and IPM module treated leaves on rearing performance of the silkworm, Bombyx mori L. Mysore Journal of Agricultural Sciences 51 (1) : 102-107.

Sik, K. Ryong, S. H. and Sang, K. R. 1976. Study of various pollutions on silkworm rearing in autumn. Sericulture Journal of Korea. 18(3):17-19.

Yokoyama, T., 1962. Synthesized Science of Sericulture. Japan, pp.. 39-46.

\section{How to cite this article:}

Yeshika. M.P., K.G. Banuprakash, K. Murali Mohan and Vinoda. K.S. 2020. Effect of Novel Insecticide Molecules in Mulberry on Cocoon Parameters of Silkworm Bombyx Mori L. Int.J.Curr.Microbiol.App.Sci. 9(02): 1027-1039. doi: https://doi.org/10.20546/ijcmas.2020.902.120 